\title{
The Indian Journal of Dairy Science
}

Vol. XXXIII

No. 1

March 1980

\section{CONTENTS}

A comparative study on the determination of solids-not-fat in milk by calculations by S. R. M. RAO and B. S. BFCTOR, I.

Composition of milk of different breeds of buffaloes by U. P. SHIARMA. S. K. RaO and I. T. ZARIWALA, 7

Thermal denaturation of goat milk whey proteins by $O . P$. KIIANidelwal. and M. P. Gupta. 13

Curd tension of milk by B. T. JaIRa.M. B. T. VIJAYALAKSHMI and P. G. NAIR, 17.

A comparative study in the lactone profile of fresh and stored ghee prepared from cow and buffalo milk by B. WADHWA. M. P. BINIJAL and M. K. JAIN. 2I.

Ghee drainage rate through residue cake and its application in the design of filtering centrifuge by A. H. ZaIDI. H. ABICHANDaNi and S. P. AliRAWALA. 24.

Uulization of goat milk for Chhana making by V. K. JAIt.KHANI and SUkUMar DE. 29.

The Physico-chemical changes in 'Coffee Complete' during storage by J. L. Bha.iumurthi. R. S. Mani and M. R. SRinivasan, 34 . A modified method for the preparation of Bhapa dahi by D. C. Bifattacharya. DFs Raj and B. D. Tiwari, 38

Physico chemical changes occurring during storage of dried ice cream mixes made from sub-standard (oxidised) butter oil by H. N. Disal and J. L. Bilanumurtili, 43.

Modified procedure for 'production of Hansa test serum. Trials with various components of buffato milk with or without adjuvants and methods of immunization by B. T. JAIRAM and P. G. NAIR. 51 .

Transaminases, urea and protein concentrations of bovine serum is influenced by dielary NPN and carbohydrate tatios by as infuenced by dietary NPN and carbohydrate tati
S. K. Biatia. K. Prablias and Ravinhir Sincih. 57.

Adaptation of biuret in goats by K. K. Siscilal and V. D. M(D)(inL. 63.

Spent colfee cake in concentrate mixtures for crossbred dairy cows by J. Raya Prasab. D. Anjanisya Prasad. P. Gupal. Reidjy and R. Raimiarawakishiva RfiJjY. 67.

Effect of ensiling on the nutritive value of wheat straw by $M . L$. Cil PTA and $K$. Prabllas. 71 .

Microbial and chemical characterization of mixed haylage of paddy straw (Orizasativa L) and dhub grass ( $C$ ynodon dacilion) by Kisitax Sivgih, S. Neflakastan and Nawab Singir, is.

Feeding value of wheal straw based poultry litter for buffalo heifers by G. S. Makkar. T. R. Cilauhan. R. S. Gili., N. S. Mal.lk and J. S. IrHH[PONANit. 83.

Studies on mortality in buffalo calves by G. S. Verma. D. K. SAIDANA, S. B. Bast: and P. A. Silarma, 87.

Skin thickness in relation to milk production in Sahiwal cows and their crosses with Brown Swiss by D. S. BHATINAGAR and SUDHIR KuMar, 91.
Cost analysis of procurement. reception and chilling of milk by Satisil K. SHarma and RaJ VIR SINGH, 95.

Milk production functions for Bundelkhand region of Uttar Pradesh by U. K. PANdey, J. P. Singih and K. S. Suhaci, 99.

Short Communications

Isolation and characterization of glycoprotein from buffalo colostrum by C. JHINGiRaN and V. MTHRA, 110

An improved gas liquid chromatography of volatile fatty acids in rumen liquor by G. K. PATEL. K. C. PAtel and R. D. PATFL. 113

Distribution of lipolytic bacteria in khoa by G. S. RAJORHIA. M. R. SRINivasan and Harish CHANDER, 116.

Mould contamination from dairy and farm environment by $P$. $K$. agciarwat, and R. A. SRinivasan, 117.

Occurrence of coliform bacteria in skim milk powder by $A$. P. S. Arun, C. R. Prasad, Basant K. Sinia and B. N. Prasad 119.

Blood cellular constituents in relation to work load in buffalo calves by NArinder Singh, V. K. GUPTA and O. P. NANGIA, 122.

Protein bound iodine in blood plasma of buffaloes in relation to postpartum anestrus by R. L. DHOBLE and S. K. GUPTA, 124.

Relationship of scrotal volume with body size, body mea surements, ejaculate volume and sperm concentration in Holstein and Jersey bulls by M. BuOSRExar, S. N. CIIAR and D. V. RANGive 125.

Effect of dietary NPN and carbohydrate ratios on feed intake and nutrient digestibility in cattle and buffalo by $S$. K. BHATIA. K. Prabitan and Randitir Singit, 127

Chemical composition and $i n$ vitro dry matter digestibility of Indian clover by B. K. Gupta. J. R. Kaushal.S. M. Biri, M. S. Somoo and A. K. Ciropra, 131

Nutritional evaluation of fodder oat varieties by N. C. Verma, A. RIKIP and I. KUMAR, 133 .

Relative performance and quality evaluation in forage maize by I. D. TYAGt and S. K. BANSAL, I36.

Relationship of serum albumin, amylase and transferrin types with performance traits in buffaloes by HAR PREET SINGH, H, K. BHAGI and G. S. BishiT, 138 .

Genetic aspects of certain physico-chemical characters of milk and milk products by B. T. Jairam. B. T. ViJaYALAKSHMI and P. G. NAIR, 141

Estimates of genetic parameters of first, second and third lactation records in buffaloes by K. S. BAwA and J. S. Dilllo,on, I44.

Conformation ratings in Sahiwal and Brown Swiss Sahiwal crossbred cows by SUDiliR KUMAR and D. S. Bilatnagar. 145

Variation in secondary sex ratio in Sirohi and its halforeds with Beelal goats by R. K. MISRA, D. GaUR and C. L. ARORA, 147.

Subscription: Rs. $40 /-$ (inland), $£ 4.00$ or $\$ 10.00$ (overseas)

Indian Dairy Association, IDA House, Sector IV,

R. K. Puram, New Delhi 110022 


\section{DIRECTIONS TO CONTRIBUTORS}

\section{GENERAL}

Two copies of manuscripts should be sent to Dr M. E. Sharpe (The Journal of Dairy Research), National Institute for Research in Dairying, Shinfield, Reading, RG2 9AT, England. Submission of a paper will be held to imply that it reports unpublished original work, that it is not under consideration for publication elsewhere, and that if accepted for the Journal it will not be published elsewhere in any language, without the consent of the Editors.

\section{FORM OF PAPERS}

The author should follow these directions carefully, and consult a current issue of the Journal for guidance on details of typographical and other conventions.

Every paper should be headed with its title, the names and initials of the authors (each author supplying one given name) and the name and address of the laboratory where the work was done.

Papers should be in English, using the spelling of the Shorter Oxford English Dictionary. They should be typed with double spacing, on one side only of the sheets, and with ample margins for editorial annotations.

Papers should in general be divided into the following parts in the order indicated: (a) Summary, brief and self-contained; (b) Introductory paragraphs, briefly explaining the object of the work but without giving an extensive account of the literature; (c) Experimental or Methods; $(d)$ Results; (e) Discussion and Conclusions; ( $f$ ) Acknowledgements without a heading; ( $g$ ) References. With some types of material headings other than $(c),(d)$ and $(e)$ may be preferable.

The use of footnotes should be avoided if possible. Underlining should be used only to indicate italics. Proper nouns, including trade names, should be given a capital initial letter. Wherever possible numerals should be used unless this leads to ambiguity. The typescript should carry the name and address of the person to whom the proofs are to be sent, and give a shortened version of the paper's title, not exceeding 45 letters and spaces, suitable for a running title in the Journal.

\section{TABLES}

Tables should be numbered and should carry headings describing their content. They should be comprehensible without reference to the text. They should be typed on separate sheets and their approximate positions in the text indicated. To minimize the cost of printing, the number and size of tables should be kept to an absolute minimum.

\section{ILLUSTRATIONS}

Line drawings and photographs, which must be originals, should be numbered as Figures in Arabic numerals. Drawings should be in Indian ink, on Bristol board or cartridge paper. However, a technique which may be more convenient to authors is to use a doublesized piece of tracing paper, or translucent graph paper faintly lined in blue or grey, folded down the centre with the drawing on one half and the other half acting as a flyleaf.

Attached to every figure and plate there should be a translucent flyleaf cover on the outside of which should be written legibly: $(a)$ title of paper and name of author; (b) figure or plate number; (c) the figures and lettering, which are intended to appear on the finished block, in the correct positions relative to the drawing underneath. Each paper should have a separate typed sheet listing figure and plate numbers with their legends, and the approximate positions of illustrations should be indicated in the text.

The photographs and diagrams should be about twice the size of the finished block and not larger overall than the sheets on which the paper itself is typed. For a figure measuring $250 \mathrm{~mm} \times 150 \mathrm{~mm}$ all lines, axes and curves should be $0.4 \mathrm{~mm}$ thick, thus Graph symbols in order of preference are $\bigcirc \bullet, \Delta \boldsymbol{\Delta}$, $\square \mathbf{\square}, \times+$, and for a $250 \mathrm{~mm} \times 150 \mathrm{~mm}$ graph the circles should be $3 \mathrm{~mm}$ in diam. The triangles should be equilateral of $3 \mathrm{~mm}$ side, and the squares also of $3 \mathrm{~mm}$ side. The crosses should have lines $3 \mathrm{~mm}$ long at right angles. Scale marks on the axes should be on the inner side of each axis and should be $3 \mathrm{~mm}$ long.

\section{SHORT COMMUNICATIONS}

Short communications or notes of not more than 2500 words or the equivalent space in print and without a summary will also be published.

\section{REFERENCES}

In the text, references should be quoted by whichever of the following ways is appropriate: Arnold \& Barnard (1900); Arnold \& Barnard (1900a): Arnold \& Barnard $(1900 a, b)$; (Arnold \& Barnard, 1900). Give all the surnames of 3 authors at the first mention, but in subsequent citations and in all cases where there are more than 3 authors give only the first surname (e.g. Brown et al.) provided that there is no possible ambiguity.

References should be listed alphabetically at the end of the paper. Titles of journals should be given in full, authors' initials should be included, and each reference should be punctuated in the typescript thus: Arnold, T. B., Barnard, R. N. \& Compound, P. J. (1900). Journal of Dairy Research 18, 158-165. References to books should include names of authors, year of publication, title, names of editors, town of publication and name of publisher in that order, thus: Arnold, T. B. (1900). Dairying. London: Brown and Chester.

It is the duty of the author to check all references.

\section{UNITS, SYMBOLS AND ABBREVIATIONS}

SI units must be used, as explained in British Standards Institution publication PD 5686:1972. The use of SI units. Until SI units are widely understood, it is permissible to give the equivalent value in other units in parenthesis. Symbols and abbreviations used are those of British Standard 1991: Part 1: 1967. Letter Symbols, Signs and Abbreviations.

\section{DESCRIPTIONS OF SOLUTIONS}

Normality and molarity should be indicated thus: $\mathrm{N}-\mathrm{HCl}, 0.1 \mathrm{~m}-\mathrm{NaH}_{2} \mathrm{PO}_{4}$. The term ' $\%$ ' means $\mathrm{g} / 100 \mathrm{~g}$ solution. For $\mathrm{ml} / 100 \mathrm{ml}$ solution the term " $\%(\mathrm{v} / \mathrm{v})$, should be used and for $\mathrm{g} / 100 \mathrm{ml}$ solution the correct abbreviation is ' $\%(w / v)$ '.

\section{OFFPRINTS}

Order forms giving quotations for offprints are sent to authors with their proofs. 


\section{CONTENTS}

\section{ORIGINAL ARTICLES}

Effect of teat skin disinfection on the rate of infection and interval to

infection in cows exposed to high levels of Staphylococcus aureus

R. F. SHELDRAKE and R. J. T. HOARE

Biological responses of the bovine teat to milking: information from

pages $1-6$

measurements of milk flow-rate within single pulsation cycles

D. M. WILLIAMS, G, A. MEIN and M. R. BROWN

Effect of atropine on plasma amino acid levels and milk secretion of cows E. ROETS and G. PEETERS

Acid-soluble nucleotides of cow's, goat's and sheep's milks, at different stages of lactation

A. GIL and F. SANCHEZ-MEDINA

The pyruvate test for monitoring the bacteriological quality of raw silo tank milk

C. M. COUSINS, U. M. RODRIGUES and R. J. FULFORD

Metabolic significance of milk glucose

A. FAULKNER, N. CHAIYABUTR, M. PEAKER, D. T. CARRICK and

N. J. KUHN

Mechanism of aggregation of casein micelles in rennet-treated milk M. L. GREEN and S. V. MORANT

Effect of milk concentration on the nature of curd formed during

renneting-a theoretical discussion

D. G. DALGLEISH

Binding of calcium ions to bovine $\beta$-casein

T G. PARKER and D. G. DALGLEISH

Calculation by computer of individual concentrations in a simulated milk salt solution. I

G. B. WOOD, D. S. REID and R. ELVIN

Calculation by computer of individual concentrations in a simulated milk salt solution. II. An extension to the previous model

R. L. J. LYSTER

Mineral balance in skim-milk and milk retentate: effect of physico-

chemical characteristics of the aqueous phase

G. BRULE and J. FAUQUANT

Effects of adding potassium iodate to milk before UHT treatment.

I. Reduction in the amount of deposit on the heated surfaces

P. J. SKUDDER, E. L. THOMAS, J. A. PAVEY and A. G. PERKIN

Effects of adding potassium iodate to milk before UHT treatment.

II. Iodate-induced proteolysis during subsequent aseptic storage P. J. SKUDDER

Heat stability of milk: interrelationship between assay temperature, $\mathrm{pH}$ and agitation

D. B. HYSLOP and P. F. FOX

Relationship between triglyceride structure and softening point of milk fat P. W. PARODI

Effect of the addition of extracts of thermophilic lactobacilli on acid

production by Streptococcus thermophilus in milk

D. H. HEMME, V. SCHMAL and J. E. AUCLAIR

Growth of morel mushroom mycelium in cheese whey

N. KOSARIC and N. MIYATA

SHORT COMMUNICATION

Role of cyanate ions in the urea-induced stabilization of the caseinate complex in skim-milk

A. W. M. SWEETSUR and D. D. MUIR

Review of the progress of Dairy Science: Bovine mastitis: milk compositional changes and related diagnostic tests

B. J. KITCHEN

(C) Proprietors of The Journal of Dairy Research 1981

Printed in Great Britain at the University Press, Cambridge 